\title{
Obraz wojen kozackich za czasów Chmielnickiego w staropolskim pamiętnikarstwie
}

Piotr Borek 


\section{Piotr Borek}

\section{Obraz wojen kozackich za czasów Chmielnickiego w staropolskim pamiętnikarstwie}

$\mathrm{P}$ roblematyka wojenna należy do dominującej w piśmiennictwie pamiętnikarskim doby staropolskiej. Liczni autorzy diariuszów i pamiętników nawiązywali w konstrukcji swych przekazów do tradycji kronikarskiej. Starali się modelować „dzieje” widziane własnymi oczyma, wykorzystując schematy wypracowane przez dzieła stricte historiograficzne. To samo można powiedzieć o zawartości tematycznej staropolskich pamiętników. Zdecydowanie przeważa w nich problematyka państwowa, publiczna nad prywatną. Co prawda zdarzają się wyjątki pokroju Jana Chryzostoma Paska, świadomie sytuującego się w centrum prezentowanej „historii”, jednak w większości tekstów z rzadka tylko wplata się „dzieje rodzinne”. Można powiedzieć, że są one zazwyczaj ujmowane o tyle, o ile wiążą się z istotnymi wypadkami w skali regionu czy też całego państwa. Czytając staropolskie pamiętniki, mamy niezatarte wrażenie „dziania się”, biegu historii. Twórcy relacji skupiają uwagę na kampaniach wojennych, poselstwach, marszach wojsk, klęskach żywiołowych, uroczystościach itp. Paradoksalnie zatem, dysponujemy fragmentarycznymi informacjami na temat zdarzeń znaczących, przełomowych, ale z punktu widzenia całego państwa. Niewiele tu natomiast danych o codziennej egzystencji mieszkańców dawnej Rzeczypospolitej, tym „zgrzebnym" bycie poszczególnych jednostek ze stanu szlacheckiego. Szlacheckiego, ponieważ w przypadku ponad $90 \%$ zachowanych tekstów ich autorami są przedstawiciele tej warstwy społecznej (pomijamy w tym miejscu rozróżnienie na teksty magnaterii i szlachty uboższej). Perspektywa „stanowa” miała kolosalne znaczenie dla sposobu ujmowania oraz interpretacji dziejów. Lektura dawnych przekazów uświadamia współczesnemu odbiorcy subiektywizm i zazwyczaj stronniczość autorów w prezentowaniu minionych zdarzeń. Należy zatem podchodzić do tego rodzaju materiału piśmienniczego $z$ wielką dozą ostrożności, mając na uwadze ich proszlachecki charakter. Identyfikacja ze stroną polską pociąga za sobą ujemną waloryzację przeciwnika; nawet wtedy, gdy zachowuje się on zgodnie z powszechnie uznawanym etosem rycerskim, to znaczy walczy mężnie w imię słuszności swej sprawy. Perspektywa propolska wpływa zazwyczaj na pewne 
„skrzywienia” realnego obrazu bitwy. Ów subiektywizm decyduje o tym, że w poszczególnych przypadkach dysponujemy raczej jednostkowymi i różnorodnymi wyobrażeniami bitwy niż suchymi, powtarzającymi się rejestracjami faktów. Stykamy się zatem z kreacyjnym wizerunkiem batalii (bliższym bądź dalszym prawdy), który dzięki temu, że został spisany, oddziaływał na wyobrażenia i sądy odbiorców, a tym samym przysłużył się do utrwalenia pewnych mentalnych stereotypów.

Rzecz jasna, „zwichnięcie” obiektywności źródła mogły warunkować różnorodne czynniki, spośród których niebagatelne znaczenie miały cele przyświecające piszącemu oraz jego miejsce w przedstawianych opisach. Wiadomo bowiem, że częstokroć pamiętniki poza funkcją poznawczą pełniły i funkcję parenetyczną. Wynikało to w pewnym stopniu, jak zaznaczono, z wzorowania się na modelu kroniki oraz, co chyba istotniejsze, z wpisywania (bezpośredniego lub pośredniego) w kreowane dzieje pouczeń dla przyszłych czytelników.

Za znaczące wydarzenia powszechnie uważano kampanie wojenne. One też w pełni zasługiwały na to, by stać się pierwszoplanowym materiałem dla tworzących relacje wspomnieniowe. W dobie staropolskiej powstało wiele diariuszów pojedynczych bitew, potyczek czy też pamiętników rejestrujących przebieg wieloletnich wojen.

W XVII wieku wojsko polskie stoczyło bodajże najwięcej batalii na ukrainnych rubieżach ${ }^{1}$. Nieustanne konflikty z Tatarami i Kozakami, powtarzające się zatargi z Moskwą i Turcją spowodowały, że mieszkańcy województw południowo-wschodnich nie czuli się bezpiecznie na tych terenach. I choć magnaci kresowi żądni szybkich zysków utrzymywali nieraz kilkutysięczne wojsko na swym żołdzie, to jednak nie byli w stanie zabezpieczyć zagrożonej granicy, która rozciągała się na setki kilometrów. Szczególnie wiek XVII obfitował w napady watah tatarskich, które równały z ziemią nie tylko chłopskie chaty czy szlacheckie dworki, lecz również podległe magnatom miasteczka. W obliczu nieustannego zagrożenia urodzajne ziemie ukrainne nie były należycie wykorzystywane. Prócz zniszczeń dokonywanych przez wrogów zewnętrznych tamtejszym mieszkańcom dawało się we znaki łupiestwo wojsk koronnych, które rozlokowywano nie tylko w królewszczyznach, ale i prywatnych dobrach. Wybieranie stacji, dopuszczanie się licznych nadużyć wobec ludności ukraińskiej z pewnością nie służyło budowie zgody między Polakami i Rusinami. Kresowa szlachta także nie czuła się pewnie w swoich majątkach. Można raczej chyba mówić o wytworzeniu się swoistej psychozy strachu przed orężem mahometan, a od połowy XVII wieku i Kozaków. Niepewność jutra i uczestnictwo w licznych bitwach i potyczkach czyniły ze szlachcica zamieszkującego tamtejsze ziemie człowieka obytego z okrucieństwem, cierpieniem i śmiercią. Nieustanne zagrożenie miało znaczący wpływ na charakter jego religijności, powodując, że był on niejako bardziej uczulony na „znaki niebieskie”. Bo też, w świetle relacji pamiętnikarskich, Ukraina zdawała się miejscem szczególnie upodobanym przez Boga. Tutaj bowiem, w powszechnym mniemaniu, częściej niż gdzie indziej karał Polaków za grzechy i nagradzał za wierność katolicyzmowi. Tu również ujawniał swe zamysły przy użyciu wojen, zaraz, komet czy innych znaków na niebie i ziemi.

1 Zob. J. Tazbir, Rzeczpospolita iświat. Studia z dziejów kultury XVII wieku, Wrocław-Warszawa-Kraków 1971, s. 63-78. 
W niniejszym szkicu ograniczono rozważania na temat obrazu zwycięskich i przegranych bitew w staropolskim pamiętnikarstwie do wypadków najważniejszych ${ }^{2}$. Podstawowym kryterium doboru analizowanych bitew stał się ponadto aspekt terytorialny. Prezentowane konflikty rozegrały się na terenach, które wchodzą w skład obecnego państwa ukraińskiego. Spośród sukcesów polskiego oręża wybrano jedynie relacje o zwycięstwie wojsk polskich pod Beresteczkiem (1651). Pamiętnikarze poświęcili na ich opisanie niejedną stronę, ponieważ Chocim (1621) i właśnie Beresteczko zdecydowały na długo, co współcześni historycy zgodnie podkreślają, o losach państwa polskiego. Na kartach pamiętników znalazły się też opisy nieudanych kampanii i klęsk wojsk koronnych. W tym przypadku do szczególowej analizy wybrano pamiętnikarskie relacje o porażce pod Piławcami. Ograniczenie się do przedstawienia dwu zaledwie batalii w pamiętnikach i diariuszach staropolskich motywowane jest kryterium typowości opisów wszelkich innych zwycięstw i klęsk. Analiza typowych relacji uświadamia, jakie z momentów walk diaryści i pamiętnikarze szczególnie mocno podkreślali, z których zaś rezygnowali. Dla egzemplifikacji określonych sądów dokonano selekcji w bogatym zasobie materiałów źródłowych. Zabieg ten wydawał się też obligatoryjny z uwagi na konieczność porównywania pewnych partii diariuszów i pamiętników poświęconych wybranemu zdarzeniu.

Bitwa pod Beresteczkiem, stoczona w 1651 roku z połączonymi siłami kozacko-tatarskimi, miała decydujący wpływ na losy całej Rzeczypospolitej Obojga Narodów ${ }^{3}$. „Wiktoryja” wojsk koronnych przywróciła blask polskiemu orężu po nieudanych kampaniach 1648 i 1649 roku. Chmielnickiemu zaś uświadomiła, że pomoc tatarska stanowi zbyt nikłą siłę, by dzięki niej można było pokonać chwiejącą się, lecz ciągle jeszcze potężną Rzeczpospolitą. W świetle ustaleń Romualda Romańskiego, w trakcie trzech dni bitwy (28-30 czerwca) zastosowano nową strategię walki, co w znacznym stopniu przyczyniło się do pokonania sił kozacko-tatarskich. Batalia miała miejsce na otwartym polu, gdzie czołową rolę odegrała jazda. W kulminacyjnym momencie zmagań ścierało się około 80 tys. wojska, co, wedle historyków, było największym zgromadzeniem kawalerii w XVII-wiecznej Europie ${ }^{4}$.

Kampania berestecka została odnotowana przez zdecydowaną większość diarystów i pamiętnikarzy, prezentujących dzieje Chmielnickiego. Sprawozdania te znacznie się różnią między sobą nie tylko rozmiarami, lecz także indywidualnym emocjonalnym odniesieniem piszących. Dysponujemy zarówno lakonicznymi notkami, w rodzaju tej, jaką pozostawił Jakub Łoś ${ }^{5}$, jak i kilkunastostronicowymi opisami (na przykład relacja Stanisława Oświęcima). Twórcy opisów batalii beresteckiej stosowali określony schemat kompozycyjny obrazu minionych zdarzeń. Pod tym

${ }^{2}$ Sprawic wojen kozackich poświçciłem obszerne partie książki Ukraina w staropolskich diariuszach i pamiętnikach. Bolnaterouie - fortece - tradycja, Kraków 2001.

${ }^{3}$ Najpełnicj do tej pory opisał batalię berestecką Romuald Romański w monografii Beresteczko 1651 (Warszawa 1994). Opis przcbicgu bitwy s. 95 in.

4 Zob. ibidem, s. 165.

5 Łoś, nicdbający o szczegóły, notował: „Tegoż roku w wilią śś. Piotra i Pawła wiclką wiktoryją otrzymali nasi pod Beresteczkiem, kędy było niemal wszystko toż wojsko, co pod Zbarażem nieprzyjacielskie. Chan sam ze wszystkimi ordami ledwie ucickł; takżc i Chmiclnicki" (Pamiętniki Eosia towarzysza choragwi pancernej Wadysłau'a margrabi Myszkowskiego, wojewody krakowskiego, obejmujqce uydarzenia od r. 1646 do 1667, wyd. Z. Pauli, Kraków 1858, s. 4). 
jednak względem teksty nie są jednorodne. Niektóre z opisów bitwy stanowią cząstkę obszernego pamiętnika bądź diariusza (miedzy innymi Mikołaja Jemiołowskiego, Stanisława Oświęcima, Joachima Jerlicza, Bogusława Radziwiłła), inne powstały jako dzienniki z przebiegu wyłącznie tej jednej kampanii ${ }^{6}$. Niezależnie od tego, czy sprawozdania stanowią teksty samoistne, czy też fragmenty większej całości, zawierają informacje o przygotowaniach, nastrojach w polskim wojsku, pierwszych potyczkach i walnej bitwie, której punkt kulminacyjny przypadł na dzień 30 czerwca 1651 roku.

Kilka krótkich polskich diariuszów o bitwie pod Beresteczkiem ${ }^{7}$ to w większości dzienniki spisane $\mathrm{w}$ formie listów do konkretnych adresatów. Ich zawartość obejmuje najważniejsze informacje, jak czas i miejsce starcia, ilość żołnierzy po obu stronach czy liczbę zabitych i rannych. Diariusze tego rodzaju ujawniają emocje piszących, uczestników relacjonowanych wypadków. Anonimowy autor tekstu zatytułowanego Gesta w obozie stwierdził, że Chmielnicki zebrał „kilkakroć sto tysięcy”, z którymi zamierzał uderzyć na Polaków. Dalej relacja zawiera opis licznych podjazdów, których celem było zdobycie informacji o Kozakach. Oto jeden z ciekawszych fragmentów:

W tych dniach poszedł był podjazd 200 koni ku Dubnu z kotarami. Zaczym, kiedy się roztaszowali, uderzyli Kozacy na nie, część wysiekli, rozproszyli, ledwie trzecią część pojmali drugich. Na szczęście, kiedy się strzelali, na ową strzelbę wyszło z Dubna ksiązęecych ludzi kilkaset koni i zaskoczyli owych otiantes i zbili, więźnie odebrali, drugich na błota wygnali i potopili. I tak niedługa ich była pociecha ${ }^{8}$.

Autor, szlachcic-żołnierz, rzetelnie przedstawia też popis pospolitego ruszenia, gdzie okazało się, że wiele osób się nie zgłosiło na kampanię („Popisało się, jakoby miało być podług chorągwi 30600 , ale bardzo siła kusych chorągwi i regimentów, i tak wszyscy rozumieją, że nad 27000 nie było”). Nie ukrywał też nędzy obozowej, przywołując zachowanie piechoty:

Piechota nam i śmiercią i nogami odchodzi srodze, częścią z głodu, bo już i konie jedzą, częścią dla pp. oficerów, którzy im dawszy złoty na tydzień, to nimi harują, a tu i na dzień słabo złoty, a innych prowiant nie sposabiają.

Wypada podkreślić owe realia obozowe, gdyż nie wszyscy diaryści i pamiętnikarze prezentują tę stronę wojny. Zgodnie natomiast podkreślają potęgę armii polskiej, a zwłaszcza kozacko-tatarskiej. Autor Pamiętników o wojnach kozackich... wyraził podziw z powodu zgromadzenia tylu tysięcy

${ }^{6}$ Zdarza się i tak, że pamiętnikarze wspominają zaledwie jednym zdaniem o dancj bitwic. Z taką skrótowością opisu bitwy beresteckiej mamy do czynienia w relacji Szymona Franciszka Pułaskiego [Krotka Annotacya Seymow... Elekcyi y Koronacyi ... corocznie odprawionych... ab Anno 1648 ad Annum 1730 Przez Im Pana Szymona Franciszka na Pulaziach Pulaskiego, Podczaszego Podlaskiego..., rps Lwowskiej Biblioteki Naukowej im. W. Stefanyka (d. Ossolincum; dalej: Stef.), zesp. 5, sygn. 2123 I, s. 154]. W celu zachowania właściwości językowych dawnych zabytków rękopiśmicnnych tytuły w przypisach podaję $\mathrm{w}$ transliteracji. W cytatach zastosowano natomiast z pewnymi modyfikacjami transkrypcjধ "typu B”.

7 Zob. Dokumenty ob oswoboditielnoj wojnie ukrainskogo naroda 1648-1654, opr. A. Z. Baraboj i in., Kijew 1965. Omawiane diariusze znajdują się na s.: 470-472, 542-544, 547-548, 594-596, 602-605.

8 Ibidem, s. 471. 
żołnierzy. W pierwszym dniu bitwy „się jego taka pokazała liczba, jakiej podobno i razu w Polszcze naszej nie było" ". Również Mikołaj Jemiołowski zaznaczał, że pod Sokalem zebrało się 40 tys. wojska, do tego zaś „prawie co godzina to więcej tak pospólstwa jako i zaciężnych przybywało ludzi”, 10 . Według Albrychta Stanisława Radziwiłła, który nie uczestniczył w kampanii, wojownicy Jana Kazimierza czynili imponujące wrażenie:

Ale gdy ustąpiła mgła, jaśniejsze słońce jakby zrywając zasłonę pokazało najpiękniej ustawione wojsko, które sam król rozciagnął prawie na pół ruskiej mili... ${ }^{11}$.

Autor podkreślał szczególną rolę Jana Kazimierza, dzięki któremu wojsko wykazywało się zdyscyplinowaniem. Było to zresztą wynikiem „musztry”, jaką władca organizował żołnierzom w trakcie marszu pod Beresteczko, co dokładnie opisał Oświęcim. Diarysta podkreślił karność armii, o czym świadczyło sprawne ustawianie szyków bojowych:

We środę o ósmej z rana (...) wyprowadzić zaraz król wojsko w pole rozkazal i przed samym obozem w lepszym szyku, niż był na papierze namalowany, one postawił ${ }^{12}$.

Podsumowując, wypada stwierdzić, że pamiętnikarze uznali za jedną z przyczyn zwycięstwa autorytet króla ${ }^{13}$ oraz zdyscyplinowanie żolnierzy.

W analizowanych tekstach na szczególną uwagę zasługują opisy samych zmagań. Fragmenty te cechuje największy rozmach epicki. Przy tym w nich właśnie ujawniają się najwyraźniej emocje piszących. W pamiętniku Jemiołowskiego spotykamy się z dwutorowym prowadzeniem narracji poprzez paralelną relację sytuacji w obozie polskim i kozackim ${ }^{14}$. Kiedy król Jan Kazimierz

...na dalszą wojnę wcześnie gotował się i wici na pospolite ruszenie wcześnie do województw wydać kazał,

wtedy też wódz kozacki, inventor omnium malorum, gromadził wojsko:

\footnotetext{
9 Pamiętniki o wojnach kozackich za Chmielnickiego przez nieznanego autora, wyd. Z. Schlctter, Wrocław 1842, s. 83.

${ }_{10}$ Pamiętnik Mikolaja Jemiolowskiego towarzysza lekkiej chorqgwi, ziemianina województwa belzkiego, obejmujacy dzieje Polski od roku 1648 do 1679 spótcześnie, porz̨̨dkiem lat opowiedziane, wyd. A. Biclowski, Lwów 1850, s. 21.

11 A. S. Radziwiłt, Pamiętnik o dziejach w Polsce, tł. i opr. A. Przyboś, R. Żclcwski, t. 3, Warszawa 1980, s. 303.

12 S. Oświçcim, Dyaryusz 1643-1651, wyd. W. Czcrmak, Kraków 1907, s. 334.

${ }_{13}$ Wiclu pamiętnikarzy podkreślało talent strategiczny Jana Kazimicrza pod Beresteczkicm. Odwaga osobista monarchy i zastosowanic nowoczcsnej taktyki walki w znacznej micrzc przyczyniły siç do ostatccznego zwyciçstwa. Na militarne walory królewskicj osoby zwracano zresztą uwag̨ i wcześnicj. Jego to odwaga i determinacja miała uratować wojsko pod Zborowem w 1649 roku. Oto opis zachowania monarchy: „Widząc to król, że nasi tył podawali, przypadł z dobytym rapierem, wołając: "Panowic, nic odstępujcie mnic i ojczyzny wszystkicj!». A kicdy już w pól obozu naszych wspierano, król i uchodzących za choragwic i wodzc chwytał, animował, drugich zabijać chciał, aby nie uciekali i dwie chorągwie tylko na posiłek, bo innych nic było, i rajtariç swoją zemknął, która pede firmo [jak wryta] stanąwszy, strzelbą nicprzyjacicla repressit [odparła]" (Opisanie zborowskiej bitưy z Kozakami d. 15 Augusta r. 1649..., rps Stef., zesp. 5, sygn. 2399 I, k. 3v).

${ }_{14}$ Autor przyjmuje w tym wypadku postawę narratora wszechwicdzącego, który doskonale się orientuje zarówno w królewskich myślach, jak równicż posuniçciach Chmiclnickicgo.
} 
Aleć i Chmielnicki nie próżnował, ale z większymi siłami niż przedtem na lacką wojnę gotował się, posławszy do pobratymców swoich [Tatarów - P. B.] z upominkami posła ${ }^{15}$.

Także w samym opisie zmagań polsko-kozackich autor stosuje epicką technikę zmiany punktu widzenia. Najpierw relacjonuje atak Jeremiego Wiśniowieckiego na tabor kozacki ${ }^{16}$, po czym, nie kończąc wątku, przechodzi do omawiania działań lewego skrzydła armii:

Tymczasem w tył Tatarom na lewe skrzydło wyuzdanym, prawe skrzydło tropem $\mathrm{z}$ armatą i piechotami następowało, $\mathrm{z}$ dział kule i granaty ogniste gęste na przyjaciela wypuszczając ${ }^{17}$.

Po opisie zwycięstwa na lewym skrzydle autor powraca do obrazu działań Wiśniowieckiego:

Polacy pustosząc z gniewu cokolwiek im na drodze zastapiło, poszło za niemi ochotnika i choragwi lekkich ordynowanych niemało i uchodzących na przeprawie rzeki Ikwy zaskoczywszy, o kilka tysięcy obywatelów tamtejszych trupem położyli, starszyzna z drugimi ustąpiła. Więc kiedy już tatarskie wojsko spędzone było tymże impetem, nasi już się wszyscy w jedno złączywszy ks. Wiśniowieckiemu sukurs dali i na kozacki tabor gwałtem nastąpili, i niemało pola kozackim trupem okrywszy do taboru już ufortyfikowanego wałami i wozami ostatek ich wpędziwszy, zaraz pewnie by ich byli za Bożą pomocą w taborze pokonali, gdyby nie wieczorny gwałtowny deszcz uderzył, który wespół z nocą marsowej przeszkodził robocie ${ }^{18}$.

Dzięki zmianie perspektywy oglądu przebiegu bitwy autor uzyskuje efekt dramatyzmu sytuacji. Takie prowadzenie narracji z pewnością wpływało na wyobraźnię odbiorcy oraz wzbudzało zaciekawienie finałami urywanych wątków. Unaocznieniu opisywanych wypadków służy też wprowadzenie do przebiegu narracji formy czasu teraźniejszego. Po zwycięskiej batalii znaczna część Kozaków zamknęła się w taborze, uniemożliwiając ostateczną likwidację armii kozackiej. Postanowiono zatem pertraktować:

Wtem stanęła rada, aby posłać kogo do nich, żeby starszyznę wydali i sami się na dyskrecję królewską poddali, aleć oni nie czekali posła naszego, lecz swoich dwóch z pokorą wyprawiwszy o miłosierdzie a żywot tylko proszą (...). Ciężkie zdały się im kondycje, a zatem na deliberacją wziąwszy i w odwłokę to puściwszy, sami między sobą się jeden na drugim polec sprzysięgają się ${ }^{19}$.

\footnotetext{
${ }^{15}$ Pamiętnik Mikolaja Jemiolowskiego..., op. cit., s. 20.

16 Zainicjowanie bitwy przez Wiśniowicckiego w przełomowym dniu podkreślają i inni pamiçtnikarzc. W relacji Bogusława Radziwiłła czytamy: „Książę Wiszniowieckie najpierwszy potrzebę zaczął, ze dwie godzinie w ustawicznym kozackim trwając ogniu..." (B. Radziwiłł, Autobiografia, wst. i opr. T. Wasilewski, Warszawa 1979, s. 130).

${ }_{17}$ Pamiętnik Mikolaja Jemiotowskiego..., op. cit., s. 24.

18 Ibidem, s. 24-25.

19 Ibidem.
} 
$\mathrm{Na}$ nieco inne aspekty przygotowań wojennych i samej bitwy zwrócił uwage anonimowy twóca Pamiętników o wojnach kozackich... Przede wszystkim hiperbolizował liczbę nieprzyjaciól („liczyło się ich więcej nad 500 000”). Zwracał też uwagę na rolę króla, od którego w znacznej mierze zawisło zwycięstwo. Wystąpił on przed bitwą z mową, w której zachęcał do stłumienia chłopskiej rebelii:

Potem król żarliwą do wojska uczynił mowę, aby tu staropolskie męstwo pokazali i hardego chłopa dzielnością pokonali. Nabrali serca nasi wielkiego z królewskiej mowy i samym pałali marsem do potkania z nieprzyjacielem ${ }^{20}$.

W opisie samego spotkania wojsk autor podkreślił rolę broni palnej ${ }^{21}$, a więc piechoty $i$ armat. Modelując obraz pola bitewnego, posłużył się metonimią i metaforą. Po ataku konnicy, dowodzonej przez Wiśniowieckiego:

...król w jego tropy ruszył się z armatą i piechotą, z którą nastąpił potężnie, ogniem bardzo hucznym i gęstym częstować począł (...). Potem chorąży koronny zahuczał ognistym grzmotem z skrzydła swego i tak dużo pod nos zakurzył chanowi, że już i Chmielnickiemu było duszno, bo nasi z nim chana rozerwali i potężnie parowali, że się wzad cofać już rozłączeni poczęlii²2.

Warto nadmienić, że wprowadzona do opisu metaforyka konstruowana była w oparciu o słownictwo potoczne, co niewątpliwie wpłynęło na plastyczność obrazowania. Pamiętnikarz stosuje również zabieg kompozycyjny polegający na paralelnym temporalnie przedstawianiu działań w różnych miejscach frontu. Gdy bowiem na jednym skrzydle chan tatarski stwierdził, ,że to nie żarty”, w innym miejscu pola bitwy rozpoczyna się rzeź Kozaków i Tatarów: „Tymczasem nasi na przeprawach jednych bili, różnie mordowali, a innych topili".

Anonimowy twórca Opisania wojny kozackiej... relacjonował beresteckie zmagania, kładąc nacisk na dramatyzm walki. Nadto w tym sensualistycznym opisie ujawniają się zwłaszcza doznania optyczne i akustyczne. Oto moment kulminacyjny bitwy:

\footnotetext{
${ }^{20}$ Pamiętniki o wojnach kozackich..., op. cit., s. 85.

${ }^{21} \mathrm{~W}$ wicku XVII zaczęła dominować bron palna nad białą. Wiązało się $\mathrm{z}$ tym zwiększenie ilości piechoty w stosunku do konnicy (nawet do 50\%). O przcbicgu bitwy nic zawsze decydowała więc szarża, lecz statyczna wymiana ognia, a męstwo w walce pojcdynczych ryccrzy wręcz przestawało się liczyć. Pamiętnikarze mają świadomość, akcentując znaczenic prochu, armat, min, że zmieniło się oblicze pola walki. Nic zawsze jednak postçp techniczny w tcj dziedzinic occniany był pozytywnic. Na przykład Wespazjan Kochowski krytykował walkę z użyciem min. Ich wykorzystanic nic pozwalalo na „sprawiedliwe” porównanie męstwa obleganych i atakujących: „Najwiçksze tych ogniów wojennych sztuki wyszły z nauk holenderskich; lecz bodajby wick nasz tych sztuk nie znał, niech Bóg Wszechmogący na ukaranie złych chowa, a ludzic niewinni i nicprzemożeni w bojach sztukami nicch nic giną! Bo kogo teraz wręcz zwyciężyć nic można, drugicmu strach w oczy spojrzeć dla mężności, sztukami niedołçżni i nikczcmni onych zwyciężaja”" (W. Kochowski, Historia panowania Jana Kazimierza..., wyd. E. Raczyński, Poznań 1840, s. 63)

${ }^{22}$ Pamiętniki o wojnach kozackich..., op. cit., s. 86.
} 
Zewrą się tedy z sobą, a że naszym i nieprzyjacielowi coraz świeże pułki na pomoc przybywają, powstanie grzmot, szczęk, huk i dym okrutny, tak dalece, że ani ludzi rozeznać, ani widzieć, kto kogo przemaga, można było ${ }^{23}$.

Stosując wyrazy dźwiękonaśladowcze („,grzmot”, „szczęk”, „huk”) i skupiając uwagę na szczególe, autor pamiętnika wykreował sugestywne i niezwykle dramatyczne obrazy, przemawiające do wyobraźni czytelnika. Przykładowo, decyzję chana o ucieczce motywował nie tyle przepędzeniem wojsk tatarskich, ile raczej wybuchem pocisku armatniego w otoczeniu wodza. Pocisk zranił śmiertelnie „znacznego murzę”, stojącego tak blisko, że „aż chana krew oprysnęła”. Dosadnych, naturalistycznych scen znajdziemy w tym przekazie więcej.

W najdokładniejszej relacji z bitwy beresteckiej autorstwa Oświęcima znajdujemy, poza licznymi łacińskimi wtrętami (ornamentacja stylu), zdania orzekające o pewnych etapach walk. I tak rozstrzygający dzień 30 czerwca rozpoczyna zwięzłe wprowadzenie:

Dzień piątkowy naznaczył P. Bóg na poniżenie hardości nieprzyjacielskiej, i na oddalenie tak oczywistych od ojczyzny, na jakie się było niebezpieczeństw ${ }^{24}$.

Poza tym diarysta, przyjmując pozycję narratora wszechwiedzącego, przypisuje niektórym osobom pewne myśli i sądy. Jan Kazimierz, widząc wielką ochotę do walki Polaków, wróżył sobie $z$ tego zwycięstwo:

Ucieszyła niepomału królewskie serce tak wielka ochota, którą nieodmiennie przyszłego, da Bóg, zwycięstwa wziął fenomen, ochotnie się do afektacyjej skłonieł i (...) przy błogosławieństwie swoim pańskim, dał do potkania ordynans ${ }^{25}$.

Jest to typowy zabieg psychologizacji postaci i jej pośrednia charakterystyka. Należy tė̇ wspomnieć, że opis Oświęcima obfituje w nazwiska żołnierzy, którzy polegli, oraz tych, którzy wsławili się szczególnym męstwem. Autor ma świadomość, że zachowuje ich imiona dla potomności, która winna czerpać z nich przykład. Podobnie też, jak inni pamiętnikarze, pomnaża liczbę nieprzyjaciół (500 tys.), co ma świadczyć o bohaterstwie i ogromie sukcesu polskiego oręża. Krocie nieprzyjacielskich trupów okupiono śmiercią zaledwie siedmiuset żołnierzy, co również, jak chciał diarysta, dodawało Polakom splendoru. Sumując wypadki pod Beresteczkiem, porównuje rozmiary zwycięstwa do bitwy grunwaldzkiej („Nie wiem, jeżeli nie tylko ojczyzna nasza, ale i świat kiedy widział, po gronwaldzkiej bitwie co podobnego"). A wszystkiego dokonał mężny Jan Kazimierz, „któremu tota otrzymanej wiktoryjej cedit gloria”26. Wzniesiona po zwycięstwie pieśń Te Deum laudamus miała poświadczyć, że było ono miłe Bogu. Interesujące, że w relacji Oświęcima

\footnotetext{
${ }^{23}$ Opisanie Woyny Kozackiey, to iest Buntow Chmielnickiego z namienieniem roznych Woien z postronnymi monarchami..., rps Stef., zesp. 5, sygn. 2098 II, k. 51v.

${ }^{24}$ S. Oświęcim, Dyaryusz..., op. cit., s. 338.

25 Ibidem, s. 339.

${ }^{26}$ Współcześni historycy podkrcślają znaczenie taktyki militarnej przyjętej w tej kampanii przez Jana Kazimierza. Zob. np. T. Wasilewski, Ostatni Waza na polskim tronie, Kraków 1984, s. 104.
} 
zupełnie brak informacji, iż zwycięstwo to nie zostało przez stronę polską należycie wykorzystane. Pozwolono bowiem na ucieczkę Kozaków z taboru i zgromadzenie nowej armii, która w rok później pokonała wojska koronne pod Batohem. Zaprzepaszczenie okazji dla zadania ciosu Kozaczyźnie było skutkiem niesubordynacji pospolitego ruszenia, które zaprotestowało przeciw decyzji króla o marszu w głąb Ukrainy i całkowitego zlikwidowania wojska zaporoskiego. Autor Pamiętników o wojnach kozackich... pisał:

Pracował długo król nad tym, chcąc ich namówić, ale na ostatek pospolitacy rozerwali się sami wrócić nazad do domów, i tak się same kwarciane wojsko bardzo zmizerowane zostało 27 .

Także Jemiołowski wspominał o „mieszaninie między szlachtą”, która w myśl umowy z królem miała służyć tylko dwa tygodnie. Pamiętnikarz konkludował:

Nieszczęsna to zaprawdę i wiele niepożyteczna, a prawie śmiertelna była klauzula ${ }^{28}$.

Dla podkreślenia politycznej szkodliwości umowy z pospolitym ruszeniem autor wprowadzil gradacyjne wyliczenie epitetów: „nieszczęsna”, ,wielce niepożyteczna”, „prawie śmiertelna”. Zabieg ten stanowi ekwiwalent jego postawy emocjonalnej wobec oburzenia, pogardy, bezsilności dla postanowień rodaków. Gradacyjnie prezentował również nastroje niezadowolonego wojska, które na początku szemrało, wkrótce jednak „niektórzy miłośnicy Rzeczypospolitej” „głośno na króla wołali, aby ich do domów rozpuszczono". Pamiętnikarze mieli więc świadomość, że przerwanie kampanii tylko na krótko przytłumi działania Chmielnickiego. Warto nadmienić, że współcześni wypadkom porównywali piławiecką klęskę z berestecką „wiktoryją” jako moralną rekompensatą za szlachecką „, hańbę”. Oświęcim zdaje się pośrednio dowodzić, iż czyn Polaków zmazał ich wcześniejszą hańbę z lat 1648-1649. Innego zdania był anonimowy autor Pamiętników o wojnach kozackich... W opisie sceny zdobycia taboru kozackiego przez Polaków nawiązał on do klęski piławieckiej:

Dopiero nasi obaczywszy obóz pusty, skoczyli i kogo tam zastali, na śmierć zabijali, wozy rabowali i znalezione rzeczy brali, jako to: siermięgi, wory i płachty, rzemienie i inne rzeczy tym podobne. Owoż naszym takowa była nadgroda za owe dostatki stracone pod Piławcami; oprócz że samej armaty niemało zabrali, wielkich półkartanów ośmnaście i strzelby także moc niemałą zastali; żywności, bydła i koni niektórym się okroiło po dostatku ${ }^{29}$.

Autor przyjmuje postawę ironisty i krytyka. Polacy bowiem nie zdobywali obozu w walce wręcz, lecz wkroczyli do niego dopiero po odejściu większości kozackiej załogi („nasi obaczywszy obóz pusty”). Stąd też ich „męstwo” podczas oblężenia taboru zostało sprowadzone do gorączko-

${ }^{27}$ Pamiętniki o wojnach kozackich..., op. cit., s. 91. Podobnie zob. u Joachima Jerlicza, Latopisiec albo kroniczka różnych spraw i dziejów dawnych i teraźniejszych czasów [...] pod rokiem [...], 1620, wyd. K. W. Wójcicki, t. 1, Warszawa 1853, s. $121 \mathrm{in}$.

${ }^{28}$ Pamiętnik Mikolaja Jemiolowskiego..., op. cit., s. 25.

${ }^{29}$ Pamiętniki o wojnach kozackich..., op. cit., s. 90. 
wego rabunku. Niechlubną kartę polskiego oręża stanowi z pewnością dokonanie rzezi niewiast i dzieci, które nie zdążyły opuścić kozackiego obozu. Po wywarciu straszliwej zemsty pospolitacy odmówili posłuchu królowi, postanawiając wrócić do „żon i poduszek”.

Pamiętnikarski obraz beresteckiej kampanii zawiera wiele monumentalnych rysów. Autorzy świadomie koloryzowali czyny rodaków, by przekazać potomności jak najlepszy wizerunek braci rycerskiej. Celowi temu służy modelowanie „świata przedstawionego” przez tendencyjny dobór faktów i subiektywizm ocen. Warto zwrócić uwagę na deprecjację przeciwników oraz jak najbardziej pejoratywne sądy na ich temat. Pomijano przy tym powody, dla których Chmielnicki wezwał na pomoc Tatarów i walczył z Polakami pod Beresteczkiem. Widziano albo raczej chciano widzieć, racje tylko jednej strony. Tendencyjność pamiętnikarzy w prezentowaniu batalii beresteckiej uchwytna jest bodaj najwyraźniej dzięki przywołaniu relacji ukraińskich. Dla przykładu warto wspomnieć poglądy Samowidca, który wcale nie dostrzega u Koroniarzy męstwa. Jako Ukrainiec, dopatruje się przyczyn klęski w zdradzie chana, który z królem polskim postanowił „coś zgodnego”, a następnie opuścił Kozaków. Ta więc „niestateczna przyjaźń wilka z baranem” stała się powodem zdrady tego pierwszego ${ }^{30}$. Oczywiście i takie oświetlenie przyczyn klęski Zaporożców mija się z prawdą.

Uproszczenia i selektywna prezentacja faktów uświadamia nam, że pamiętniki wykraczają poza zwykły tekst dokumentarny i wiążą się z konwencją literacką, tworzącą rzeczywistość fikcyjną. Pamiętnikarskie opisy bitew z pewnością stoją na pograniczu dokumentu i dzieła literackiego, choć bliższe są pierwszemu działowi piśmiennictwa. Elementy fikcjonalizacji pojawiają się choćby w obrazach ingerencji Opatrzności w rzeczywistość ziemskiej wojny. Pod Beresteczkiem, wg Radziwiłła, Polacy zwyciężyli dzięki opiece Boga i Bogarodzicy ${ }^{31}$. Jemiołowski wyrażał przekonanie, że to modlitwa i obecność wizerunku Najświętszej Panny w obozie doprowadziły do sukcesu ${ }^{32}$. Autor Pamiętników o wojnach kozackich... przywołał „znaki”, które miały jakoby świadczyć o zwycięstwie Jana Kazimierza:

Tak gdy się rzeczy dzieją, aż nad samym obozem pokazał się święty Michał na powietrzu z Najświętszą Maryją Panną, który jakoby za chanem gonił, grożąc mu mieczem; z czego nasi uweseleni niezwyciężonego prawie nabierali serca ${ }^{33}$.

\footnotetext{
${ }^{30}$ Zob. Lietopis' Samowidca po nowootkrytym spiskam s potożenijem triech chronik: Chmielnickoj, „Kratkaho Opisanija Małorosji” $i$,Sobranija Istoricieckaho”..., opr. O. Liewickij, Kijcw 1878, s. 24-25. Wypada stwicrdzić, żc zarówno rclacje polskic, jak i ukraińskic dalekic były od obicktywnej prawdy. Wzajemna nicchçć wymuszała zrozumiały subicktywizm.

31 Zob. A. S. Radziwiłł, Pamiętnik..., op. cit., s. 306.

32 Zob. Pamiętnik Mikolaja Jemiolowskiego..., op. cit., s. 24-25.

${ }^{33}$ Pamiętniki o wojnach kozackich..., op. cit., s. 85-86. Idąc najpewniej za tradycją ustną i swoistym mitem opicki Bożcj nad Polską, po latach przywolał ten obraz jezuita Szymon Majchrowicz: „Za Jana Kazimicrza sama Najjaśnicjsza Królowa nicba i ziemi, Najświętsza Maryja przeciwko Chmiclnickicmu pokazała siç w obłokach płaszczem okrywająca polski sobie pobożny naród. W tejże samej bitwie widziany był świçty hetman wojsk aniclskich, Michał, pioruny spuszczający na Chmielnickiego Tatarów..." (S. Majchrowicz, Trưlošć szczęstiwa królestw, albo ich smutny upadek wolnym narodom przed oczy stauiona na utrzymanie nieoszacounanej szczęstiw'ości su'ojej, cz. 2, Lwów 1764, s. 35-36). Na marginesie wypada dodać, że „faktyczny” obraz cudownej ingerencji został poddany dalcko idącym przckształceniom. Właściwie pozostały tylko persony, natomiast ich czyny uległy zmianic. W religijnym kontekścic rozpatrywał
} 
Wprowadzając takie sceny, autorzy dawali wyraz powszechnym wierzeniom. Ze „znakami Bożymi" spotykamy się bowiem nie tylko w pamiętnikarstwie, lecz historiografii, kaznodziejstwie czy barokowych eposach rycerskich. Ich biblijnej proweniencji nie trzeba dowodzić.

Podsumujmy rozważania na temat pamiętnikarskiego obrazu zwycięskiej bitwy, jaką Polacy stoczyli w obrębie przestrzeni ukrainnej. Diaryści i pamiętnikarze ujmują materię zdarzeniową w chronologicznym porządku, stosując zazwyczaj trójdzielny schemat kompozycyjny: wprowadzenie o charakterze ogólnym, właściwy opis bitwy, refleksję podsumowującą kampanię (ostatni element rzadziej obecny w diariuszach). Większość autorów, pomimo werystycznej techniki w przedstawianiu historycznych wypadków, dokonuje heroizacji czynów swych ziomków poprzez zastosowanie licznych zabiegów stylistycznych i kompozycyjnych: uwypuklanie momentów walki, w których dominowali Polacy, tendencyjne bilansowanie strat i zdobyczy, ośmieszanie przeciwnika i tym podobne. Pamiętniki, jako teksty o charakterze narracyjnym, cechuje ponadto plastyczność i dynamizm w obrazach prezentujących zmagania armii. Modelowanie tych scen stanowi bez wątpienia wynik świadomej decyzji pisarskiej. Realna rzeczywistość wojenna posiada przy tym w relacji narracyjnej dwa wymiary. Po pierwsze, stanowi rejestrację realnie zaistniałych wypadków, często poświadczonych wiedzą z autopsji, po wtóre, wartościowana jest jako moralny fakt zmagań sacrum i profanum. Ze sferą pozytywów zawsze związana jest strona polska. Uproszczona struktura pamiętnikarskiego „obrazu świata”, nieco schematyczna i fragmentaryczna, nie pozbawia wszakże tych tekstów charakteru dokumentarnego. Znajdziemy w nich bowiem wiele fragmentów oddających grozę wojny. Autorzy mówią o chorobach, zarazie, głodzie, nędzy, okrucieństwie, cierpieniu, śmierci, a także niezadowoleniu wojska i buntach. Teksty te, pomimo wymienionych powyżej tendencji do ubarwiania, stanowią doskonały i autentyczny zapis przeżywania zwycięskiej wojny. Są wyrazistym obrazem stanu świadomości piszących, który w następnych pokoleniach podlegał mitotwórczym przekształceniom.

Na ukrainnych polach miały również miejsce sromotne klęski Polaków. To właśnie tutaj, wedle niektórych pamiętnikarzy, szlacheccy wojownicy „nauczyli się uciekać” przed wrogiem; po raz pierwszy pod Cecorą (1620), a następnie w dobie Chmielnickiego. Zatem relacje pamiętnikarskie zawierają nie tylko opisy sukcesów militarnych, lecz również niepowodzeń wojsk koronnych.

Spośród obrazów klęski, które przywoływali twórcy relacji wspomnieniowych, do dokładniejszej analizy wybrano piławiecką z 1648 roku. Wybór nie jest przypadkowy, gdyż to włánie ona zmieniła sytuację polityczno-gospodarczą całej Rzeczypospolitej Obojga Narodów, ponieważ w jej wyniku Chmielnicki objął zasięgiem swojego działania tereny od Zadnieprza aż pod Lwów i Zamość, zaś doprowadzając do ruiny majątki szlacheckie, bezpośrednio niszczył stan polskiego posiadania na południowo-wschodnich krańcach Korony. Klęska piławiecka przesądziła i to, iż w czasie sejmu elekcyjnego po śmierci Władysława IV liczono się ze zdaniem hetmana zaporoskiego, popierającego kandydaturę Jana Kazimierza, który zgodnie z oczekiwaniami Kozaka, objął 
ostatecznie tron polski. Piławce miały też i inne, nie mniej doniosłe znaczenie. Oto bowiem, w tej właśnie kampanii, wielotysięczne wojsko polskie opuściło swój obóz, nie staczając decydującego boju. Wydarzenia piławieckie odbiły się szerokim echem nie tylko w diariuszach i pamiętnikach, lecz i w poezji. Kampanię tę nazywano klęską „plugawiecką” i wstydzono się tchórzostwa rodaków.

Jak zatem przedstawiali klęskę „plugawiecką” polscy diaryści i pamiętnikarze? Otóż na wstępie wypada stwierdzić, że relacje na ten temat nie są w pamiętnikach tak obszerne, jak w przypadku zwycięskich kampanii. Przez niektórych autorów opisy ucieczki są wspomniane lakonicznie. W pamiętniku Łosia znajdziemy jedynie krótką wzmiankę:

Tegoż roku podczas interregnum Rzeczpospolita wyprawiła wojsko dość wielkie w liczbie i okazałości, pod dyrekcyją księcia Władysława Dominika Ostrogskiego wojewody krakowskiego, które spod Piławiec sromotnie uciekło, odbieżawszy wszystkich dostatków, które były nieoszacowane (albowiem tak się byli pp. wybrali, jako na wesele) co wszystko dostało się Kozakom ${ }^{34}$.

W rozbudowanym, wielokrotnie złożonym zdaniu Łoś zawarł informacje o czasie wyprawy, dowódcy oraz ucieczce wojska i stratach materialnych. Przy tym ironicznie skomentował ów „przepych” armii, stosując porównanie do wesela. Brak tu oczekiwanych motywacji samej wyprawy oraz ucieczki. Autor poprzestał na suchej konstatacji faktów. Jest to jednak skrajny przykład pamiętnikarskiego obrazu nieszczęścia pod Piławcami. Zazwyczaj bowiem autorzy poświęcali tej sprawie więcej uwagi. Niektórzy, jak na przykład anonimowy twórca Diariusza errorów..., podkreślali wojskowe rozprzężenie w polskim obozie:

W obozie nulla disciplina, nulla wodzów auctoritas, w nocy po haśle strzelano, wołano, czego nikomu nie ganiono, bo była poena metus unius ad omnes, za czym żadnego nie było porządku ${ }^{35}$.

Tym samym diarysta informował odbiorcę o przyczynach nieszczęścia jako wyniku niesubordynacji żołnierzy. Fakt ten odnotował i Jemiołowski:

Atoli na początku września wojsko polskie pod Piławce przeciwko Chmielnickiemu ruszyło się i tam niesfornością swoją na onych polach górzystych i miejscami błotnistych do boju niesposobnych stanęło 36 .

Do klęski, jak wynika z powyższego cytatu, znacznie przyczyniła się błędna decyzja regimentarzy, którzy założyli obóz w niefortunnym strategicznie miejscu ${ }^{37}$. Warto tu nadmienić, że armia polska

\footnotetext{
${ }^{34}$ Pamiętniki Eosia..., op. cit., s. 2. Z ostatnio wydanych prac podejmujących wątek piławiccki warto przywołać pracę Władysława A. Serczyka, Na plonacej Ukrainie. Dzieje Kozaczyzny 1648-1651, Warszawa 1998, s. 139 i n. Por. tcż: P. Jasienica, Rzeczpospolita Obojga Narodów, t. 2, Warszawa 1985, s. 28-28; W. Konopczyński, Dzieje Polski nowożytnej, opr. M. Nagielski, t. 2, Warszawa 1996, s. 404.

${ }^{35}$ Dyaryusz Errorów Ichmśc PP. Regimentarzów pod Pilaw'ami, rps Biblioteki Czartoryskich w Krakowic (dalej: BCzart.), sygn. IV 143, s. 119 i n.

${ }^{36}$ Pamiętnik Mikołaja Jemiołouskiego..., op. cit., s. 7. Por. też M. Vorbek Lettow, Skarbnica pamięci. Pamiętnik lekarza króta Wladystawa IV, opr. E. Galos, F. Mincer, red. W. Czapliński, Wrocław-Warszawa-Kraków 1968, s. 159.

${ }^{37}$ Fakty te potwierdzil autor Pamiętników o wojnach kozackich...: „Po uczynionej lustracyi ruszyli sic̨ hetmani spod
} 
nie od razu pierzchła przed wrogiem. Bowiem w dniach 21-22 września doszło do szeregu potyczek z wojskiem kozackim, które bez pomocy Tatarów nie było w stanie stawić czoła Polakom:

...gdziekolwiek bowiem nieprzyjaciel pokazał się, tam albo na placu poległ, albo z wielką swoją stratą do taboru uchodzić musiał ${ }^{38}$.

Niestety, wieczorem 22 września do kozackiego obozu weszły wojska tatarskie, co miało przesądzić o przebiegu dalszych wypadków. Ów moment, który można by uznać za jeden $z$ decydujących dla piławieckiej klęski, odnotowało wielu pamiętnikarzy. Podkreślali oni haniebną ucieczkę wojsk koronnych na wieść o posiłkach tatarskich dla Kozaków; tym haniebniejszą, że bez przyjęcia walnej bitwy. Autor Pamiętników o wojnach kozackich... pisał:

Aż pod wieczór, gdy już z pola poczęli jeżdżać szwadrony, stał się huk jakiś w obozie Chmielnickiego, bo w bębny uderzono, w surmy, w trąby zagrano, potem $z$ armat bić poczęto. Zdziwili się nasi, co by za przyczyna takowego była triumfu, i nic inszego na myśl nie przyszło, tylko to wnosili, że chan tatarski przyszedł z wojskiem do Chmielnickiego, i dlatego Kozacy witają 39.

O wplywie tego zdarzenia na nastroje w polskim obozie wypowiedział się i Jemiołowski, akcentując głównie wybuch paniki wśród żołnierzy:

Tymczasem Tuhaj bej co i pierwej sułtan tatarski w kilkadziesiąt tysięcy wojska cichusieńko w nocy trzeciej z wojskami kozackimi złączył się, co jako tylko podsłuchy polskie postrzegli i z tą nowiną do obozu pospieszyli, zaraz z nagła starszyznę tak bardzo ta trwoga poturbowała, że zaraz konie juczyć kazali, a wrzkomo z sobą radząc, jakoby dalej postąpić sobie mieli, już o ustąpieniu z pola myśleli. Postrzegłszy to wojsko, co żywo do juków brać się poczęło ${ }^{40}$.

Dla Albrychta Radziwiłła sytuacja ta stała się pretekstem do moralizatorskiej, ogólniejszej refleksji:

Przybycie kilku tysięcy Tatarów pokrzepiło wroga, zaś naszych tak pozbawiło zapału do prowadzenia wojny, że tak wielkie wojsko, które mogło zdobyć Konstantynopol, zaczęło przemyśliwać o ucieczce i uznało sprawę za straconą. Zaiste, najprawdziwsza to $\mathrm{rzecz}$, iż lepsze jest wojsko jeleni z wodzem lwem niż wojsko lwów z wodzem jeleniem. W nocy więc z 22-go na 23-go, kiedy starszyzna,

Glinian pod Piławce, gdzie sic̨ też i książę złączył, alc jak nieszczęśliwie, że wojsko tam się zgromadziło: bo najpierwcj staje to obozem między górami, dołami, a do tego nieszcz̨̧ścia i rządów wicle było, dlatego sic̨ i w dyspozycyi miçszało, którcj wszyscy wodzowie, każdy z osobna apretendował, miçdzy którymi była wiclka dyscnsyja" (s. 21). Zob. też: Z Warszaury relacja pogromu wojska polskiego pod Pilawcami. Anno Domini 1648, w: Dokumenty ob oswoboditielnoj wojnie..., op. cit., s. 117-118.

${ }^{38}$ Pamiętrik Mikolaja Jemiolowskiego..., op. cit., s. 7.

${ }^{39}$ Pamiętriki o wojnach kozackich..., op. cit., s. 22.

${ }^{40}$ Pamiętnik Mikotaja Jemiolowskiego..., op. cit., s. 7. 
bez ujawniania komukolwiek tego zamiaru, potajemnie rzuciła się do ucieczki, wszyscy rozbiegli się; wozy, żywność, uzbrojenie, łupy zostawiono pierwszemu, któremu posłuży szczęście ${ }^{41}$.

Radziwiłł snuje parenetyczną refleksję na temat roli i odpowiedzialności wodzów podczas prowadzenia wojen. W podtekście zawarta jest oczywista krytyka nieudolności i tchórzostwa regimentarzy, którzy swym zachowaniem dali zły przykład całej armii.

Najplastyczniej diaryści przedstawili sam moment ucieczki wojska polskiego w nocy z 22 na 23 września 1648 roku. Autorzy wprost prześcigali się w kreowaniu karykatur uciekinierów. Większość, oskarżając armię o tchórzostwo, nie współczuła ściganym i grabionym rodakom.

W tym miejscu warto przytoczyć kilka wypowiedzi, by ukazać z jednej strony ogrom hańby, z drugiej zaś sposób komponowania opisów i nastrój narratorów-pamiętnikarzy. Anonimowy autor Nowin z pogromu... zwracał uwagę na dobytek, z jakim wybrali się Polacy na wojnę:

Wojska natenczas dochodziło 30000 oprócz czeladzi luźnej, której było na 30 000, bo samych wozów, które byli naładowali w Polsce wydzierstwem przeszło 50000.

Bogactwa jednak „nie pomogły” polskiej armii, która na wieść o Tatarach zaczęła „umykać”. Diarysta, ironizując, przywołuje łacińską sentencję, szczególnie popularną wśród sarmackich potomków. W kontekście kampanii piławieckiej interpretuje ją na opak:

Obaczywszy wodzowie takie następowanie nieprzyjaciela (...) sprośnie uchodzili, bo się tego nauczyli, iż salvare patriam nie co innego rozumieć potrzeba, tylko dobre uciekanie, a zwłaszcza ci, co wiedzieli o Tatarach i tchórzową bojaźnią zarażeni byli.

Opowiadający, sam dwa razy postrzelony w czasie odwrotu, niezwykle obrazowo oddał w kolejnych partiach relacji zachowanie wojska. Zwrócił też uwagę na postępowanie Kozaków i Tatarów, którzy nie wierząc w możliwość paniki w polskim obozie, myśleli, że ,jakie stratagema nasi czynią (...) i całe dwie godziny nie uderzyli”. Dopiero po tym czasie rozpoczęli rzeź Polaków i grabież obozu, co autor oddał $z$ epickim rozmachem:

Tatarowie i Kozacy (...) widziawszy, iż choragwie daleko odpadają, nawet się różnie dzielą, z okrzykiem wpadli do obozu; tam wszelkie dostatki pobrali, a nad tymi, którzy się bronili, tyraniją czynili, i choć kto uciekał, tego nie goniono, tak dalece, iż niewielka w ludziach stała się szkoda. Ale w rynsztunku i dostatkach jest szkody więcej niż siedem milijonów, a ignomina niesławy na tysiąc milijonów, bo przy rządzie dobrym a przy wodzach Boga się bojących, szczęśliwa i niepochybna mogła być wiktoryja; ale to luxus, ambicyja, niezgoda, invidia winna; luxus, bo jeden miał diamentowy rząd i rubinowy za sto tysięcy, a drugi taką ferezyją sobolową, w którą się Tatarzyn ubrał, z pętlicami diamentowymi i sobolami kosztownymi, kosztowała na siedemdziesiąt tysięcy (...). W uchodzeniu tym nieszczęsnym zwłaszcza z Piła-

${ }^{41}$ A. S. Radziwiłł, Pamiętnik..., op. cit., s. 112. 
wiec do Konstantynowa, jeden drugiego $z$ konia zrzucał, a dla tłumu wielkiego i zatarasowania wozów, jedni się wplaw puściwszy, tamże zostawali, a drudzy z mostu przy natarczywości swojej się [szyje?] łamali (...). Luźnych białogłów pięć tysięcy było, które w obozie i pod obozem były, ale ich Tatarowie ani Kozacy nie uszanowali, bo ich, miasto gorzałek, miodów, błotem i krwią częstowali ${ }^{42}$.

W anonimowym diariuszu na uwagę zasługuje podkreślenie przez jego twórcę hańby, którą się okryli Polacy. Wynikała ona zarówno z porzucenia dostatków i opuszczenia pola walki, jak również z kłótni w czasie odwrotu. Za przyczyny ucieczki diarysta uznał: zły „rząd”, wewnętrzną niezgodę w polskim obozie, „ambicyje” dowódców, zazdrość, prywatę i nadmierny luxuıs. Dodatkowo, co wypada szczególnie podkreślić, autor mówi o okrucieństwie wrogów wobec bezbronnych kobiet oraz żołnierzy, którzy nie zdążyli salwować się ucieczką. Zachowanie współrodaków podobnie określili inni pamiętnikarze. Dla szlachcica spisującego Pamiętniki o wojnach kozackich... punktem centralnym obrazu stała się scena porzucenia dobytku i atak wroga na obóz:

Tymczasem strwożone wojsko pierzchać i uchodzić poczęło taborem (...) rzucali wszyscy owe swoje wymyślne dostatki, kredensy i serwisy srebrne, rzędy bogate, ordynki, pałasze suto złote, sobole, wilczury i rysie, suknie bławatne, pasy perskie, owo zgoła co najmilszego być mogło, wszystko się rzucało, a żywo się uciekało. Cóż tu rozumieć, jak tam siła młodzi polskiej naginęło? Bo jedni nie bywszy przedtem w okazyi i razu, w betach i puchach pod namiotami się wylegali i porwawszy się podczas trwogi, sami z sobą nie wiedząc, co robić mieli i gdzie uciekać, od dzid kozackich dusze postradali, a insi tonęli w błotach i mizernie także ginęli. Owoż na co to wyszły owe do obozu pobrane dostatki! Słowem mówiąc, obóz nasz cały zniesiony został; którzy jednak z tej okazyi wyjść mogli, sami nie wiedząc, dokąd uciekali ${ }^{43}$.

${ }^{42}$ Nouriny z pogromu uojska polskiego pod Piłaucani r. 1648, w: Nouriny o Chmielnickim. Fortelna i przemyslna zdrada Chmielnickiego pryncypała..., Biblioteka Naukowego Zakładu Imicnia Ossolińskich 1847 [Lwów], t. 2, s. 8-13.

${ }^{43}$ Pamiętniki o wojnach kozackich..., op. cit., s. 24. Przywołanic i omówicnic wszystkich opisów ucickająccgo wojska spod Piławicc zajçłoby zbyt wicle micjsca. W związku z tym, na zasadzie kontekstu, podano w tym micjscu dwa ciekawszc spośród wielu innych. Bogusław Kazimicrz Maskicwicz, wykorzystujący relacje świadków, notował: „Plaga tam Pańka była, żc nasi, nie widząc nic na siç gwałtowncgo, poczçli picrzchać i tak sromotnic ucickać, żc siç drugi o kilkadziesiąt mil ledwie obcjrzał. A tego przyczyną był nicszczçsny Bclzcbub książ̨ Dominik, który miał sobic poruczoną buławę wiclką od Rzeczypospolitej do powrotu hetmanów z więzienia i ten najpierwcj strwożywszy sobą, nocą ucickł. Wojsko też nic widząc hetmana, co żywo od wszystkicgo. Nieprzyjacicl tego nic spostrzcgłszy, dzień stał nad obozem, bojąc się nań natrzeć, rozumicjąc, żc się lud utaił, potem gdy począł następować, widzi, że się nikt nic broni, opanował wszystko. Tam jakową mial zdobycz, któż to wicdzicć możc, bo panowic koronni cum tali luxu [z takim przepychem] wybrali siç od purpurowych ze złotymi wçzłami nie tylko rydwanów, ale skarbnych wozów, od szat, srebra, złota, klejnotów obicia etc., tak żc rzadki towarzysz nic równał siç panom wiclkim w dostatku, by i ostatnią substancyją przedać, a dostatnie siç ustroić, takowy to tam zbytek, za który Pan Bóg ich znacznic pokarał, bo od wszystkicgo uciekali, choć ich nikt nie gonił. Czym wieczną niezmazaną makulę [plamę] i hańbę na ojczyznę wewlekli" (Pamiętniki Samuela i Bogustawa Kazimierza Maskieuiczów (wiek XVII), opr. A. Sajkowski, Wrocław 1961, s. 258-259). Tomasz Józefowicz zaś stwierdził: „Dobry Boże! Jakie wiclkie oni [wrogowic — P. B.] tam znaleźli skarby, kiedy przez długi pokój szczęśliwi panowic i szlachta bogata więccj złota i srebra z sobą do obozu przywiozła niż żelaza prżeciw nieprzyjaciołom! Któż klęskç owcj nocy, któż śmierć opowicdzieć lub opisać, któż łzami wyrównać zdoła?" (T. Józefowicz, Kronika miasta Lwowa od roku 1634 do $1690 \ldots$.., tł. M. Piwocki, Lwów 1854, s. 107). W dalszych partiach autor wylicza bogactwa, które padły łupem wroga. Obrazy klęski zawarli ponadto, m.in.: J. Jerlicz (Latopisiec..., op. cit., s. 70), M. Jemiołowski, wedle którego Kozacy „pozostałych szlachtę i żołnierzów jak kapustę w picń 
Ten niezwykle plastyczny obraz, mający wywołać u odbiorcy jasno określone emocje, jednocześnie wyrażał osobiste oburzenie autora. Pamiętnikarz posłużył się wyliczeniem „dostatków”, które żolnierze zabrali ze sobą na wyprawę. Świadczyć to miało o ich bogactwie, ale też o pysze i pewności siebie. Wykorzystując zespół retorycznych środków (wyliczenie, pytanie retoryczne, wykrzyknienie), twórca sugestywnie oddziałuje na wyobraźnię i nastrój odbiorcy. Stara się też przekonać czytelnika o głupocie, nieodpowiedzialności i tchórzostwie obrońców. Warto też zwrócić uwagę na dynamizm omawianej sceny, która doskonale oddaje trwogę chaotycznie umykającego wojska koronnego. Pamiętnikarz zastosował tu technikę obrazowania polegającą na przechodzeniu od szczegółowości relacjonowanych wypadków do uogólniającej pointy: „Słowem mówiąc, obóz nasz cały zniesiony został". Wszystkie wykorzystane środki stylistyczne wpływają na hiperbolizację pogromu wojsk polskich w nocy z 22 na 23 września.

Albrycht Radziwiłł zaprezentował klęskę piławiecką w kontekście wyroków nieba i Bożej kary za popełnione grzechy:

Uciekali więc przez nikogo nie ścigani, nie pomni na szlachectwo, na wstyd, na to, w jakim stanie pozostaje Rzeczpospolita, na wszystkich im drogich, tak iż słusznie o nich można to powiedzieć: „Tysiąc pierzchnąłby przed jednym, a 10 tysięcy przed dwoma", ale tutaj nawet nikt nie ścigał, a pierzchali wszyscy, a to dlatego, że Bóg ich odstąpił i Pan o nich rozstrzygnął. Duma, swoboda, ucisk biednych te na nich nacierały. Ledwie 1000 ludzi stracili we wszystkich trzech starciach z nieprzyjacielem. Sami siebie zgubili i nas byliby zgubili, gdyby Bóg i Bogarodzica nie pospieszyli z pomocą i nie opóźnili zamiarów wroga 44 .

Autor, jako jeden z nielicznych, dostrzega w panice Polaków wyrok Opatrzności. Bóg odstąpił szlachtę, według Radziwiłła, na skutek nadmiernego ucisku poddanych i grzechu pychy. W powyższym fragmencie uwidacznia się głębokie przekonanie piszącego, że to nie człowiek decyduje o losach bitwy, lecz Stwórca, przepędzający tysiące przez ,jednego" 45 bądź „dwóch”. Pamiętnikarz motywuje klęskę Polaków ich nadmierną pychą i pewnością wygranej:

Lecz gdy niemal ogłupiali przed zwycięstwem trąbią na tryumf, to kończą w smutku i czyny ich stają się pastwą wieczystej niesławy ${ }^{46}$.

Na koniec warto przywołać relację uczestnika nieszczęsnej kampanii, który opisywał nie tylko losy wojska, lecz, dodatkowo, opis wydarzenia wzbogacił wątkiem osobistym: własną peregrynacją do domu:

siekli, dostatki w wozach porzucone szarpali" (Pamiętnik Mikolaja Jemiolowskiego..., op. cit., s. 7-8), Samowidiec (Lietopis'..., op. cit., s. 14), Natan Hanower (Jewein Mecula..., op. cit., s. 44 i n.), autor Dyaryusza Errorów... (op. cit., s. 119-126), twórca Pamiętrików do panowania Zygmunta III (wyd. K. W. Wójcicki, t. 1, Warszawa 1846, s. 12 i n.) oraz anonim w Kroniczce lat 1621-1657, rps Biblioteki PAN w Kórniku, sygn. BK 312, k. 116.

${ }^{44}$ A. S. Radziwiłl, Pamiętnik..., op. cit., s. 113.

${ }^{45} \mathrm{~W}$ podtekście uchwytne jest nawiązanie do starotestamentowych ksiąg Biblii, gdzie Bóg karze klęskami wojennymi naród izraelski za różnorodne przewiny (por. np.: Joz 7, 1-9; Sdz 20, 14-28; $2 \mathrm{Krl}$ 17, 7-23; $1 \mathrm{Krn} \mathrm{10,1-7).}$

${ }^{46}$ A. S. Radziwiłł, Pamiętnik..., op. cit., s. 112. 
A my niebożęta, pułk województwa sandomierskiego, biliśmy się z nimi, póki jeno sił naszych i końskich stawało, a gdy już potędze pogańskiej wytrzymać nie mogli, ostatek czego nie zbito w potrzebie, na onę przeprawę złą napędzono nas, gdzie Tatarowie dojeżdżając nas, siekli, a Kozacy na tejże przeprawie z wyrychtowanych dział bili nas (...). Jam przez stawa przepłynął, jeszcze i w zbroi, dziwnym sposobem Pan Bóg mię wyniósł $z$ tej potrzeby, gdzie natenczas spod mojej chorągwie zginęło towarzystwa pod trzydzieści, krom pachołków, tamże natenczas syn mój zginą ${ }^{47}$.

Przekaz ten utrwalił indywidualną tragedię człowieka tracącego zarówno przyjaciól, jak i potomka. Co ciekawe, w tej nasyconej realiami scenie autor poprzestaje na wyliczeniu zabitych, nie ujawniając wszakże uczuć względem utraconych towarzyszy oraz własnego dziecka. I jest to chyba wynikiem nie tyle „poetyki gatunku”, co ówczesnej świadomości żołnierza-ojca, który godzi się z prawami bezdusznej wojny.

W przedstawieniach klęski piławieckiej pamiętnikarze ustosunkowali się do walczących negatywnie. Opisy przegranych bitew w relacjach wspomnieniowych są bardzo szczególowe i realistyczne. Zawierają informacje o: miejscu i czasie batalii, liczbie wojowników w obu armiach, zachowaniu żołnierzy itp. Można mniemać, że znaczna część barokowych poetów odwoływała się do diariuszów bitewnych przy komponowaniu własnych wierszy ${ }^{48}$. Dzienniki bowiem stanowiły rodzaj źródla historycznego, charakteryzującego się „wiarygodnością”. Pamięć piławieckiej klęski była niezwykle żywotna. Jeszcze król Jan III Sobieski wspominał, że matka, ucząc synów patriotyzmu, przywoływała to zdarzenie:

A po owej nieszczęsnej piławieckiej ekspedycjej, nie po jeden kroć mawiała, że „gdyby tak który z synów moich miał ujść z potrzeby, nigdy bym go nie miała za syna" 49 .

Wojna zajmowała centralne miejsce w staropolskich diariuszach i pamiętnikach. Prezentowano w nich zarówno sukcesy militarne wojska polskiego, jak również chwile klęsk. Momenty radości i smutku przedstawiano w sposób realistyczny. Obrazy bitew charakteryzują się sensualistycznym ukonkretnieniem oraz dramatycznością, która wynika ze stanowczych zabiegów stylistycznych (nagromadzenie czasowników, wyliczenia, wykrzyknienia, pytania retoryczne, mowa niezależna). Co ciekawe, na kartach pamiętników i diariuszów więcej miejsca zajmują opisy zwycięstw polskiego oręża. Dokładniejsza analiza sukcesów wpływa na uszczegółowienie relacjonowanych scen.

Jak już wspomniano, pamiętnikarskie opisy pól bitewnych stanowią zapis szlacheckiej świadomości wojny, z którą brać szlachecka stykała się osobiście o wiele częściej niż współczesne nam pokolenia. W XVII wieku, zwłaszcza na rubieżach ukrainnych, toczono bitwy co kilka bądź

\footnotetext{
47 Relacja Pana Zaborowskiego Rotmistrza Pana Sandomierskiego z Obozu uchodzącego, rps BCzart., sygn. IV 143, s. $161-162$.

48 Konfliktom polsko-kozackim poświęcono współcześnie wiele tekstów poetyckich. Część z nich zebrał J. Nowak-Dłużewski w pracy Okolicznościowa poezja polityczna w Polsce. Dwaj mlodsi Wazowie, Warszawa 1972, s. 89-150.

${ }^{49}$ Excerpt $z$ manuscriptu wlasnej ręki Nayiánieyszego króla Jego Mci s.p. Jana Trzeciego, w: Pisma do wieku i spraw Jana Sobieskiego, zebr. i wyd. F. Kluczycki, t. 1, cz. 1, Kraków 1880, s. 8-9.
} 
kilkanaście lat. Ludzie byli oswojeni z orężem i śmiercią. W pamiętnikach nie znajdziemy wielu uwag na temat żalu, smutku po poległych współrodakach, osobach najbliższych (wyjątek stanowią wybitni wodzowie). Śmierć na polu bitwy stanowiła bowiem wypełnienie etosu rycerskiego. Diaryści podkreślali natomiast waleczność Polaków w czasie zwycięskich kampanii lub, w przypadku klęski, negatywne cechy wojsk koronnych. O wartościowaniu decydował zazwyczaj ogólny wynik bitwy. Wiadomo jednak skądinąd, że pod Piławcami znalazło się wielu mężnych rycerzy, którzy woleli zginąć niż „podać tył”. W pamiętnikach jednak uogólnia się wypadki, co z pewnością wpływa na pewną jednostronność autorskich sądów. Autorzy relacji modelowali schematyczny, uproszczony obraz przedstawionego świata. Tak było i w przypadku opisów bitewnych. Selektywność prezentowanej materii zdarzeniowej wpłynęła w znacznym stopniu na wykreowanie rzeczywistości „dualistycznej”. Pamiętnikarska przestrzeń pola walki podzielona została na obszar działania „swoich” i „obcych”. Waloryzacja owych fragmentów przestrzennych była jednoznacznie określona. Polaków wiązano ze sferą pozytywów, wrogów nigdy. 